\title{
Terapi Cairan Prarujukan dan Skor PELOD sebagai Prediktor Mortalitas Sindrom Syok Dengue Anak
}

Eka Permata Sari, Pudjo Hagung Widjajanto, Nurnaningsih

Departemen Ilmu Kesehatan Anak Fakultas Kedokteran Universitas Gadjah Mada RSUP Prof. Dr. Sardjito, Yogyakarta

Latar belakang. Sindrom syok dengue (SSD) merupakan kondisi kegawatan yang dapat meningkatkan morbiditas dan mortalitas. Manajemen cairan yang tidak adekuat di pelayanan kesehatan prarujukan merupakan salah satu faktor yang berkontribusi terhadap mortalitas pada SSD. Skor Pediatric Logistic Organ Dysfunction (PELOD) dapat digunakan sebagai prediktor mortalitas SSD.

Tujuan. Menilai hubungan dan mortalitas terapi cairan prarujukan dengan skor PELOD dalam 24 jam pertama di Pediatric Intensive Care Unit (PICU).

Metode. Penelitian rancangan kohort retrospektif pada anak SSD yang dirawat di RSUP Dr. Sardjito bulan April 2011 - Maret 2016. Subjek dengan serologi dengue positif baik yang datang sendiri ke IGD ataupun rujukan dilakukan penilaian skor PELOD. Analisis bivariat chi-square digunakan untuk menilai hubungan terapi cairan prarujukan, skor PELOD dan mortalitas.

Hasil. Terdapat 159 subyek berusia 1 bulan -18 tahun. Hubungan bermakna terdapat pada skor PELOD $\geq 20$ terhadap mortalitas SSD $(\mathrm{p}<0,05)$. Namun, tidak terdapat hubungan antara resusitasi cairan prarujukan dengan skor PELOD dan mortalitas $(\mathrm{p}>0,05)$. Kelebihan cairan prarujukan meningkatkan kematian 2,8 kali meskipun secara statistik tidak bermakna $(\mathrm{p}=0,06)$.

Kesimpulan. Resusitasi prarujukan tidak berpengaruh terhadap mortalitas SSD anak. Skor PELOD $\geq 20$ memiliki mortalitas yang tinggi pada SSD anak. Kelebihan cairan prarujukan meningkatkan mortalitas SSD. Sari Pediatri 2017;18(5):357-62

Kata kunci: SSD, terapi cairan, skor PELOD, mortalitas

\section{Pre-referral Fluid Therapy and PELOD Score as a Predictor of Mortality in Pediatric Dengue Shock Syndrome}

Eka Permata Sari, Pudjo Hagung Widjajanto, Nurnaningsih

Background. Dengue shock syndrome (DSS) is an emergency condition with high morbidity and mortality. Inadequate fluid management at pre-referral health centre is one of the contributing factor to mortality rate. Pediatric Logistic Organ Dysfunction (PELOD) score can be used as a predictor for mortality in DSS.

Objective. To assess the role of pre-referral fluid therapy and PELOD score at the first 24 hours after Pediatric Intensive Care Unit (PICU) admission and mortality.

Methods. This study is a retrospective cohort study of pediatric DSS who were admitted to Sardjito Hospital from April 2011 March 2016. Samples with positive dengue serology that came to emergency room by themselves or referral case were assessed for PELOD score. Chi-square analysis is used to assess the association between pre-referral fluid therapy, PELOD score and mortality.

Results. 159 subjects aged 1 month -18 years old were included in the study. There was significant difference between PELOD score $\geq 20$ and DSS mortality $(\mathrm{p}<0,05)$, but no significant differences between pre-referral resuscitation and PELOD score and mortality $(\mathrm{p}>0,05)$. Pre-referral fluid overload increased the mortality 2,8 times even there was no significant difference $(\mathrm{p}=0,06)$.

Conclusions. Pre-referral resuscitation doesn't affect mortality in pediatric DSS. PELOD score $\geq 20$ has a high mortality outcome in pediatric DSS. Pre-referral fluid overload increases the mortality. Sari Pediatri 2017;18(5):357-62

Keyword: DSS, fluid therapy, PELOD score, mortality

Alamat korespondensi: Dr. Eka Permata Sari. Departemen Ilmu Kesehatan Anak, Fakultas Kedokteran Universitas Gadjah Mada/RSUP dr. Sardjito. Jl. Kesehatan No.1 Sekip, Sinduadi, Mlati, Sleman. Yogyakarta. 55284. Email: ekaps82@gmail.com 
S indrom syok dengue (SSD) adalah suatu kegawatan pada penyakit infeksi virus dengue. Prevalensi SSD anak di dunia sekitar 37,4\%. ${ }^{1}$ Angka kematian SSD dalam kurun waktu 45 tahun terakhir menurun dari 41\% di tahun 1968 menjadi $0,73 \%$ di tahun $2013 .{ }^{2} \mathrm{Hal}$ ini berkaitan dengan semakin baiknya tata laksana SSD. Di RSUP Dr. Sardjito, Yogyakarta, angka kematian SSD pada rentang tahun 2006-2012 mencapai 27\%, faktor prognostik yang berpengaruh terhadap kematian adalah manajemen cairan prarujukan yang tidak adekuat, perdarahan mayor, dan syok berkepanjangan. ${ }^{3}$

Pada demam berdarah dengue (DBD), terjadi kebocoran plasma dan gangguan koagulasi darah. Kebocoran plasma terjadi selama 24-48 jam sejak hari ketiga sakit. ${ }^{4}$ Cairan intravena berperan penting dalam manajemen SSD. Resusitasi awal dilakukan dengan pemberian cairan kristaloid, tetapi jika tidak membaik, dilanjutkan dengan cairan koloid hingga obat inotropik. ${ }^{5}$ Namun, akumulasi cairan secara klinis dan radiologis tampak meningkatkan risiko distres respirasi pasien SSD hingga 40\% sehingga memperberat kondisi pasien. ${ }^{6,7}$ Luaran mortalitas SSD dengan keterlibatan 1 organ atau lebih dapat dinilai dengan skor PELOD berdasarkan data saat masuk dan keluar atau dari masuk hingga 2 jam sebelum kematian. ${ }^{8}$ Leteurtre ${ }^{9}$ mengembangkan skor disfungsi organ pada anak meliputi gangguan sistem neurologi, kardiologi, respirologi, nefrologi, hepatologi, dan parameter hematologi. Skor PELOD digunakan untuk menilai derajat keparahan pada disfungsi setiap organ. ${ }^{10}$ Kondisi penyakit kritis meningkatkan mortalitas hingga 50\% jika skor PELOD 20 atau lebih. ${ }^{11}$ Skor PELOD yang diambil dalam 24 jam pertama di PICU dapat digunakan untuk memprediksi keluaran mortalitas pasien SSD. Organ yang banyak bermasalah pada SSD berdasarkan skor PELOD adalah gangguan hepar dan hematologi. ${ }^{12,13}$

Pasien SSD yang datang ke rumah sakit tersier berasal dari pelayanan kesehatan tingkat I dan atau II ataupun pasien yang datang sendiri. Berdasarkan observasi, sebagian besar kasus SSD prarujukan telah mendapatkan resusitasi cairan berupa kristaloid, koloid hingga obat inotropik atau vasoaktif. Selain itu, terdapat pula kasus yang mendapatkan terapi cairan melebihi cairan rumatan selama perawatan sehingga meningkatkan risiko kelebihan cairan. Penelitian mengenai hubungan antara skor PELOD dengan tata laksana terapi cairan prarujukan terhadap mortalitas pasien SSD masih sedikit.

\section{Metode}

Penelitian rancang kohort retrospektif dengan data rawat 24 jam pertama di PICU RSUP Dr. Sardjito, Yogyakarta. Data rekam medis pasien diambil dengan kuesioner mulai bulan April 2011 - Maret 2016. Kriteria inklusi adalah anak usia 1 bulan -18 tahun yang dirawat di PICU dengan diagnosis SSD berdasarkan hasil pemeriksaan antigen dengue NS-1 positif ataupun serologi antibodi anti-dengue IgG dan atau IgM positif. Kriteria eksklusi jika rekam medis tidak ditemukan atau tidak lengkap, SSD teratasi, atau pulang atas keinginan sendiri.

Penilaian gangguan respirasi dengan penilaian rasio $\mathrm{PaO} 2 / \mathrm{FiO} 2$ : a: penilaian rasio $\mathrm{PaO} 2 / \mathrm{FiO}_{2}$ dan pemakaian ventilator, ${ }^{\text {b}}$ : penilaian kesadaran dan reaksi pupil, ${ }^{\text {c: }}$ nilai kreatinin, ${ }^{\mathrm{d}}$ : penilaian nadi dan tekanan darah, e: nilai SGOT, waktu protombin atau INR, f: nilai lekosit dan trombosit. Keterangan: ${ }^{a}$ : Resusitasi adekuat jika mendapat kristaloid atau kristaloid dan koloid $20-60 \mathrm{ml} / \mathrm{kg} /$ pemberian, dengan atau tanpa inotropik/ vasoaktif/vasodilator, ${ }^{\mathrm{b}}$ : Resusitasi tidak adekuat jika anak langsung dirujuk saat diketahui syok tanpa mendapat resusitasi atau cairan resusitasi $>60 \mathrm{ml} / \mathrm{kg} /$ pemberian, ${ }^{c}$ : berdasarkan penemuan klinis ronkhi basah basal di paru dan atau edema paru secara radiologis

Semua subjek penelitian dilakukan penilaian skor PELOD pada 24 jam pertama perawatan di PICU. Semua data diolah dengan SPSS 20.0. Dilakukan analisis bivariat chi square dan Fisher's exact test untuk menilai hubungan antara resusitasi prarujukan dan skor PELOD terhadap luaran mortalitas dan hubungan antara resusitasi prarujukan terhadap skor PELOD.

\section{Hasil}

Karakteristik umum subjek penelitian terdiri atas jenis kelamin, usia, status gizi, hari demam saat masuk ke PICU, jumlah kasus rujukan, kejadian syok berulang prarujukan, resusitasi prarujukan, dan kejadian kelebihan cairan prarujukan (Tabel 1). Di antara 159 kasus SSD yang dirawat di PICU didapatkan $31(19,5 \%)$ kasus meninggal. Terdapat $148(93,1 \%)$ kasus prarujukan dengan $41(27,7 \%)$ kasus mengalami syok berulang sebelum dirujuk dan $16(10,8 \%)$ kasus kelebihan cairan prarujukan.

Didapatkan SSD dengan skor PELOD $<20$ 
dan $\geq 20$ masing-masing $126(79 \%)$ dan $33(21 \%)$ kasus. Mortalitas yang sangat tinggi dijumpai pada skor PELOD $\geq 20$ dengan RR 89,9 ( $<<0,05$; IK95\% 26,5-305,5). Dari analisis masing-masing penyebab kegagalan organ pada skor PELOD terhadap mortalitas didapatkan hasil yang bermakna pada gangguan neurologi, kardiologi, nefrologi, respirologi, dan hepatologi $(\mathrm{p}<0,05)($ Tabel 2$)$.

Di antara 148 kasus yang dirujuk, 90 kasus telah mendapat resusitasi prarujukan. Tidak didapatkan hubungan bermakna antara kasus yang telah mendapat resusitasi, kelebihan cairan prarujukan (berdasarkan penemuan klinis ronki basah basal di paru dan atau edema paru secara radiologis) ataupun dengan volume cairan resusitasi $>60 \mathrm{ml} / \mathrm{kg} /$ pemberian terhadap mortalitas dan skor PELOD ( $>>0,05)$. Kelebihan cairan meningkatkan kematian hingga 2,8 kali lipat (Tabel 3 dan 4).

Tabel 1. Karakteristik subjek penelitian

\begin{tabular}{|c|c|c|c|c|}
\hline \multirow[t]{2}{*}{ Karakteristik } & \multicolumn{2}{|c|}{ Meninggal } & \multicolumn{2}{|c|}{ Hidup } \\
\hline & $\mathrm{N}$ & $\%$ & $\mathrm{~N}$ & $\%$ \\
\hline \multicolumn{5}{|l|}{ Jenis kelamin } \\
\hline Laki-laki & 12 & 15,8 & 64 & 84,2 \\
\hline Perempuan & 19 & 22,9 & 64 & 77,1 \\
\hline \multicolumn{5}{|l|}{ Usia (tahun) } \\
\hline $0-5$ & 13 & 23,2 & 43 & 76,8 \\
\hline $5-10$ & 16 & 21,3 & 59 & 78,7 \\
\hline$>10$ & 2 & 7,1 & 26 & 92,9 \\
\hline \multicolumn{5}{|l|}{ Status gizi } \\
\hline Baik & 25 & 22,7 & 85 & 77,3 \\
\hline Buruk & 1 & 7,7 & 12 & 92,3 \\
\hline Kurang & 1 & 6,2 & 15 & 93,8 \\
\hline Overweight & 4 & 26,7 & 11 & 73,3 \\
\hline Obese & 0 & 0,0 & 5 & 100,0 \\
\hline \multicolumn{5}{|c|}{ Hari demam saat masuk ke PICU (hari) } \\
\hline $1-3$ & 2 & 28,6 & 5 & 71,4 \\
\hline $4-6$ & 28 & 19,0 & 119 & 81,0 \\
\hline$>6$ & 1 & 20,0 & 4 & 80,0 \\
\hline \multicolumn{5}{|l|}{ Kasus rujukan } \\
\hline Ya & 29 & 19,6 & 119 & 80,4 \\
\hline Tidak & 2 & 18,2 & 9 & 81,8 \\
\hline \multicolumn{5}{|l|}{ Kejadian syok berulang pra rujukan } \\
\hline Ya & 7 & 17,1 & 34 & 82,9 \\
\hline Tidak & 22 & 20,6 & 85 & 79,4 \\
\hline \multicolumn{5}{|l|}{ Resusitasi prarujukan } \\
\hline Tidak adekuat $^{\mathrm{a}}$ & 11 & 19,0 & 47 & 81,0 \\
\hline Kristaloid & 12 & 19,0 & 51 & 81,0 \\
\hline Koloid & 4 & 28,6 & 10 & 71,4 \\
\hline Inotropik/vasoaktif/vasodilator & 2 & 15,4 & 11 & 84,6 \\
\hline \multicolumn{5}{|l|}{ Kelebihan cairan prarujukan ${ }^{\mathrm{b}}$} \\
\hline Ya & 6 & 37,5 & 10 & 62,5 \\
\hline Tidak & 23 & 17,4 & 109 & 82,6 \\
\hline
\end{tabular}

Keterangan: ${ }^{a}$ tidak mendapatkan resusitasi atau volume cairan resusitasi $<20 \mathrm{ml} / \mathrm{kg} /$ pemberian, ${ }^{\mathrm{b}}$ berdasarkan penemuan klinis ronki basah basal di paru dan atau edema paru secara radiologis 
Eka Permata Sari dkk: Terapi cairan prarujukan dan skor PELOD sebagai prediktor mortalitas SSD

Tabel 2. Hubungan skor PELOD dengan mortalitas SSD

\begin{tabular}{|c|c|c|c|c|c|c|c|}
\hline \multirow[t]{2}{*}{ Kategori } & \multicolumn{4}{|c|}{ Luaran } & \multirow[t]{2}{*}{ Total } & \multirow{2}{*}{$\begin{array}{c}\text { RR } \\
\text { (IK95\%) }\end{array}$} & \multirow[t]{2}{*}{$\mathrm{p}$} \\
\hline & \multicolumn{2}{|c|}{ Meninggal $(\mathrm{n}=31)$} & \multicolumn{2}{|c|}{ Hidup (n=128) } & & & \\
\hline \multicolumn{8}{|c|}{ Skor Pelod, n (\%) } \\
\hline$\geq 20$ & 26 & 78,8 & 7 & 21,2 & 33 & 89,9 & 0,00 \\
\hline$<20$ & 5 & 4,0 & 121 & 96,0 & 126 & $(26,5-305,5)$ & \\
\hline \multicolumn{8}{|c|}{ Gangguan respirasi ${ }^{\mathrm{a}}$} \\
\hline $\mathrm{Ya}$ & 29 & 58,0 & 21 & 42,0 & 50 & 73,9 & 0,00 \\
\hline Tidak & 2 & 1,8 & 107 & 98,2 & 109 & $(16,7-333,5)$ & \\
\hline \multicolumn{8}{|c|}{ Gangguan neurologis ${ }^{\mathrm{b}}$} \\
\hline Ya & 25 & 59,5 & 17 & 40,5 & 42 & 27,2 & 0,00 \\
\hline Tidak & 6 & 5,1 & 111 & 94,9 & 117 & $(9,7-75,9)$ & \\
\hline \multicolumn{8}{|c|}{ Gangguan renal ${ }^{\mathrm{c}}$} \\
\hline $\mathrm{Ya}$ & 8 & 66,7 & 4 & 33,3 & 12 & 10,8 & 0,00 \\
\hline Tidak & 23 & 15,6 & 124 & 84,4 & 147 & $(2,9-38,8)$ & \\
\hline \multicolumn{8}{|c|}{ Gangguan kardiovaskulard } \\
\hline Ya & 23 & 38,3 & 37 & 61,7 & 60 & 7,1 & 0,00 \\
\hline Tidak & 8 & 8,1 & 91 & 91,9 & 99 & $(2,9-17,2)$ & \\
\hline \multicolumn{8}{|c|}{ Gangguan hepatik } \\
\hline $\mathrm{Ya}$ & 25 & 32,1 & 53 & 67,9 & 78 & 5,9 & 0,00 \\
\hline Tidak & 6 & 7,4 & 75 & 92,6 & 81 & $(2,3-15,4)$ & \\
\hline \multicolumn{8}{|c|}{ Gangguan hematologif } \\
\hline Ya & 28 & 21,4 & 103 & 78,6 & 131 & 2,3 & 0,15 \\
\hline Tidak & 3 & 10,7 & 25 & 89,3 & 28 & $(0,6-8,1)$ & \\
\hline
\end{tabular}

Tabel 3. Hubungan tatalaksana resusitasi prarujukan dengan mortalitas SSD

\begin{tabular}{|c|c|c|c|c|c|c|c|}
\hline \multirow{3}{*}{ Kategori } & \multicolumn{4}{|c|}{ Luaran } & \multirow{3}{*}{ Total } & \multirow{3}{*}{$\begin{array}{c}\text { RR } \\
\text { (IK95\%) }\end{array}$} & \multirow{3}{*}{$\mathrm{p}$} \\
\hline & \multicolumn{2}{|c|}{ Meninggal } & \multicolumn{2}{|c|}{ Hidup } & & & \\
\hline & $\mathrm{N}$ & $(\%)$ & $\mathrm{n}$ & (\%) & & & \\
\hline \multicolumn{8}{|c|}{ Resusitasi adekuat } \\
\hline $\mathrm{Ya}^{\mathrm{a}}$ & 18 & 20,0 & 72 & 80,0 & 90 & 1,1 & 0,53 \\
\hline Tidak $^{\mathrm{b}}$ & 10 & 17,5 & 47 & 82,5 & 58 & $(0,5-2,5)$ & \\
\hline \multicolumn{8}{|l|}{ Resusitasi } \\
\hline$>60 \mathrm{ml} / \mathrm{kg}$ & 1 & 14,3 & 6 & 85,7 & 7 & 0,7 & 0,57 \\
\hline$\leq 60 \mathrm{ml} / \mathrm{kg}$ & 17 & 20,5 & 66 & 79,5 & 83 & $(0,1-5,7)$ & \\
\hline \multicolumn{8}{|c|}{ Kelebihan cairan ${ }^{c}$} \\
\hline $\mathrm{Ya}$ & 6 & 37,5 & 10 & 62,5 & 16 & 2,8 & 0,06 \\
\hline Tidak & 23 & 17,4 & 109 & 82,6 & 132 & $(0,9-8,6)$ & \\
\hline
\end{tabular}

\section{Pembahasan}

Pada penelitian kami, angka kematian SSD adalah $19,5 \%$, lebih rendah dibandingkan penelitian sebelumnya dengan karakteristik yang serupa di RSUP dr. Sardjito tahun 2006-2012 (27\%). ${ }^{3}$ Semakin baiknya pelayanan mulai dari penegakan diagnosis dan terapi didukung oleh kapasitas sumber daya manusia seiring dengan perkembangan ilmu pengetahuan, dapat menurunkan angka kematian SSD. Kejadian SSD lebih banyak terjadi pada usia 5-10 tahun (47,2\%), jumlah laki-laki sebanding dengan perempuan. Hal ini berbeda dengan penelitian di Malaysia yang menyatakan kejadian SSD lebih banyak terjadi pada usia $>12$ tahun dan lebih banyak pada laki-laki. ${ }^{14}$

Resusitasi yang tidak adekuat prarujukan (39,2\%), berasal dari kasus yang tidak mendapat resusitasi cairan saat syok atau mendapat resusitasi berlebih dengan jumlah cairan $>60 \mathrm{ml} / \mathrm{kg}$. Cairan resusitasi yang digunakan untuk mengatasi SSD pertama kali 
Eka Permata Sari dkk: Terapi cairan prarujukan dan skor PELOD sebagai prediktor mortalitas SSD

Tabel 4. Hubungan tata laksana resusitasi prarujukan dengan skor PELOD

\begin{tabular}{|c|c|c|c|c|c|c|c|}
\hline \multirow[t]{3}{*}{ Kategori } & \multicolumn{4}{|c|}{ Luaran } & \multirow[t]{3}{*}{ Total } & \multirow{3}{*}{$\begin{array}{c}\text { RR } \\
\text { (IK95\%) }\end{array}$} & \multirow[t]{3}{*}{$\mathrm{p}$} \\
\hline & \multicolumn{2}{|c|}{ Skor PELOD $\geq 20$} & \multicolumn{2}{|c|}{ Skor PELOD $<20$} & & & \\
\hline & $\mathrm{n}$ & $(\%)$ & $\mathrm{N}$ & $(\%)$ & & & \\
\hline \multicolumn{8}{|c|}{ Resusitasi adekuat } \\
\hline Ya & 17 & 18,9 & 73 & 81,1 & 90 & 0,7 & 0,29 \\
\hline Tidak & 14 & 24,1 & 44 & 75,9 & 58 & $(0,3-1,6)$ & \\
\hline \multicolumn{8}{|c|}{ Resusitasi (ml/kg) } \\
\hline$>60$ & 1 & 14,3 & 6 & 85,7 & 7 & 0,7 & 0,61 \\
\hline$\leq 60$ & 16 & 19,3 & 67 & 80,7 & 83 & $(0,1-6,2)$ & \\
\hline \multicolumn{8}{|c|}{ Kelebihan cairan } \\
\hline Ya & 6 & 37,5 & 10 & 62,5 & 16 & 2,6 & 0,09 \\
\hline Tidak & 25 & 18,9 & 107 & 81,1 & 132 & $(0,9-7,7)$ & \\
\hline
\end{tabular}

adalah larutan kristaloid dan jika tidak ada perbaikan dilanjutkan dengan koloid dan atau inotropik. Hal ini sejalan dengan pendapat Nhan ${ }^{15}$ yang melaporkan bahwa pemberian kristaloid dan koloid memberikan respon yang lebih baik daripada koloid saja pada syok dengan selisih tekanan nadi yang sempit.

Risiko mortalitas SSD dengan skor PELOD $\geq 20$ dua kali lebih besar dibandingkan dengan pasien kritis lainnya yang dirawat di PICU. ${ }^{16}$ Syok hipovolemik pada SSD diperberat dengan gangguan vaskulopati dan koagulopati sehingga sering terjadi perdarahan, kebocoran plasma masif yang tidak bisa diimbangi dengan penggantian cairan resusitasi, dan kejadian efusi pleura bilateral. ${ }^{16,17}$ Pasien SSD memiliki risiko mortalitas yang tinggi jika sudah terjadi syok berkepanjangan dan kegagalan organ multipel. ${ }^{18}$

Pada penelitian sebelumnya salah satu faktor prognostik yang berpengaruh terhadap mortalitas SSD adalah manajemen cairan yang tidak adekuat sebelum pasien dirujuk ke rumah sakit tersier. Kami tidak mendapatkan hubungan antara kejadian kasus resusitasi prarujukan yang tidak adekuat, kejadian kelebihan cairan, pemberian jenis dan jumlah cairan resusitasi, terhadap mortalitas SSD. Deteksi dini dan tata laksana SSD yang agresif dan pemberian terapi diuretik pasca syok secara selektif dapat menurunkan mortalitas pada kejadian kelebihan cairan. ${ }^{18}$

Kelebihan cairan pada SSD meningkatkan kematian hingga 2,8 kali lipat, dan gangguan respirasi pada skor PELOD memiliki kontribusi terbesar terhadap kematian. Kelebihan cairan menyebabkan penumpukan cairan di jaringan paru sehingga terjadi edema paru sehingga beban kerja paru bertambah dan meningkatkan distres pernapasan. Sutawan $\mathrm{dkk}^{19}$ menyebutkan kelebihan cairan menyebabkan kematian 11,5 kali lipat lebih besar pada pasien dengan penyakit kritis di PICU.

Dari penelitian kami, didapatkan bahwa skor PELOD dalam 24 jam pertama perawatan PICU ber peran penting untuk memprediksi mortalitas pada SSD. Pengenalan awal tanda syok dan resusitasi yang tepat, tetap memainkan peranan yang penting terhadap luaran SSD. Kelemahan dari penelitian retrospektif bahwa tidak semua subjek dilakukan pemeriksaan secara lengkap sehingga tidak dapat dimasukkan dalam analisis.

\section{Kesimpulan}

Resusitasi prarujukan tidak berpengaruh terhadap mortalitas SSD anak. Skor PELOD $\geq 20$ memiliki mortalitas yang tinggi pada SSD anak. Kelebihan cairan prarujukan meningkatkan mortalitas SSD.

\section{Daftar pustaka}

1. Huy NT, Giang TV, Hirayama K, dkk. Factors associated with dengue shock syndrome: a systematic review and meta-analysis. PloS Negl Trop Dis 2013;7:e2412-32.

2. Karyanti MR, Uiterwaal CSPM, Bruijning-Verhagen P. The changing incidency of dengue haemorrhagic fever in Indonesia: a 45 year registry-based analysis. BMC Infectious Diseases 2014;14:1-7.

3. Pangaribuan A, Prawirohartono EP, Laksanawati IS. Faktor prognosis kematian sindrom syok dengue. Sari Pediatri 2014;15:332-41. 
4. Sellahewa KH. Pathogenesis of dengue hemorrhagic fever and its impact on case management. ISRN Infect Diseas 2013; 1-6.

5. Wills BA, Dung NM, Farrar JJ. Comparison of the three fluid solutions for resuscitation in dengue shock syndrome. $\mathrm{N}$ Engl J Med 2005; 353:877-89.

6. Rosenberger KD, Lum L, Alexander N, Junghanss T, Wills B, Jaenisch T. Vascular leakage in dengue - clinical spectrum and influence of parenteral fluid therapy. Trop Med Int Health 2016. doi:10.1111/tmi.12666.

7. Wills B. Volume replacement in dengue shock syndrome. Dengue Bulletin 2001;25:50-5.

8. Lacroix J, Cotting J. Severity of illness and organ dysfunction scoring in children. Pediatr Crit Care Med 2005;6:S1126-34.

9. Leteurtre S, Duhamel A, Leclerc F. Daily estimation of the severity of multiple organ dysfunction syndrome in critically ill children. JMAC 2010;182:1181-7.

10. Thukral A, Kohli U, Lodha R, Kabra SK, Arora NK. Validation of the PELOD score for multiple organ dysfunction in children. Indian Pediatrics 2007;44:683-6.

11. Metta D, Soebardja D, Hudaya DS. The use of pediatric logistic organ dysfunction (PELOD) scoring system to determine the prognosis of patients in pediatric intensive care units. Paediatr Indones 2006;46:1-6.

12. Dewi LP, Nurfitri E. Pediatric logistic organ dysfunction score as a predictive tool of dengue shock syndrome outcomes.
Paediatr Indones 2012;52:72-7.

13. Iskandar HR, Mulyo D, Agnes P, Suryatin Y. Comparison of pediatric logistic organ dysfunction (PELOD) score and pediatric risk of mortality (PRISM) III as a mortality predictor in patients with dengue shock syndrome. Pediatrics 2008;121:S12-20.

14. Jamaimah I, Rohela M, Nissapatorn V. Prevalence of DF and DHF in Hospital Tengku Ampuan Rahimah, Klang, Selangor, Malaysia. Southeast Asian J TROP Med Public Health 2005; 36:196-201.

15. Nhan NT, Phoung CXT, Farrar J. Acute management of dengue shock syndrome: a randomized double blind comparison of 4 intravenous fluid regimens in the first hour. CID 2001;32:204-13.

16. World Health Organization. National guidelines for clinical management of dengue fever. India. 2015.

17. Suharti C, Setiati TE, Van Gorp ECM. Risk factors for mortality in dengue shock syndrome (SSD). M Med Indones 2009;43:213-219.

18. Ranjit S, Kissoon N, Jayakumar I. Aggresive management of dengue shock syndrome may decrease mortality rate:A suggested protocol. Pediatr Crit Care Med 2005;6:412-9.

19. Sutawan IBR, Wati DK, Suparyatha IBG. Association of fluid kelebihan with mortality in pediatric intensive care unit. Crit Care Shock 2016;19:8-13. 